Editorial, part of a Special Feature on Bridging Conservation and Development in Latin America and Africa: Changing Contexts, Changing Strategies

\title{
Conservation and Development in Latin America and Southern Africa: Setting the Stage
}

\author{
$\underline{\text { Claudia Romero }}{ }^{1}, \underline{\text { Simone Athayde }}^{2}, \underline{\text { Jean-Gael E. Collomb }}^{3}, \underline{\text { Maria DiGiano }}^{4}, \underline{\text { Marianne Schmink }}^{1}, \underline{\text { Sam Schramski }}^{4}$, and \\ $\underline{\text { Lisa Seales }}^{4}$
}

ABSTRACT. The articles in this Special Feature stem from a 2010 conference (Bridging Conservation and Development in Latin America and Africa) organized by the University of Florida's Tropical Conservation Development Program, Center for African Studies, and Center for Latin American Studies. The conference involved researchers and practitioners from Africa and Latin America focused on the complex and evolving relationship between conservation and development. The conference provided bridges between academics and non-academics, conservation and development, and theory and practice. The resulting comparative analyses focus on: empowerment of local institutions; enhanced capacity of local and regional stakeholders through a recognition and validation of local knowledge systems and the creation of knowledge networks; understanding of social and natural landscapes, history, contexts, and their evolution; and the roles of economic and market forces in shaping opportunities for using market-based incentives to promote conservation and development. In this introductory article we propose a conceptual framework based on the six connected pillars of natural resource characteristics, interactions of social actors, governance and participation, politics, information exchange, and economic issues that support spaces for both conflicts and synergies between conservation and development goals. Our goal is to foster informed dialogue and social learning to promote sustainability.

Key Words: Africa, complex social-ecological systems, conservation, development, knowledge networks, local institutions, economic incentives; Latin America.

\section{INTRODUCTION}

Environmental conservation and rural development have long represented dichotomies in research and practice, embedded in contrasting ideologies about society and nature, and often times contradictory problem solving approaches, with few points of intersection. Conservation scientists, practitioners, and policy makers are familiar with this conservation and development debate, and with the frequent disconnect among scientific research results, policy making, and implementation. The increasing recognition of how intertwined human societies are with nature forces us to rethink the notion of conservation and development as separate and dichotomous. Rather, they must be seen as two end points of a bridge, in which each side strengthens and girders the other, providing support for the mutual objective of improved well-being of the planet and its inhabitants. The articles in this volume explore some of the potential architecture of that bridge.

Conservation science has made significant progress towards highlighting and unpacking the complex, and yet pivotal, strategic trade-offs required to pursue sustainable outcomes (Nelson et al. 2009, Minteer and Miller 2011). Evidence of this paradigm shift may be seen in both research and practice, including: emerging frameworks that recast the relationship between conservation and development (Carter 1980, Salafsky and Wollenberg 2000, Wunder 2001, Brechin et al.
2002, Sayer and Campbell 2004, Fitzgerald and Stronza 2009, Campbell et al. 2010); integration of sustainable natural resource management with enhanced well-being for rural communities (Roe and Elliott 2004, Raudsep-Hearne et al. 2010, Barrett et al. 2011); the emergence of sustainability as a science (Clark and Dickson 2003); and initiatives to evaluate program effectiveness in terms of both conservation and development goals (Milder et al. 2010, Oldekop et al. 2010, Keene and Pullin 2011, Salafsky 2011).

In this Special Issue, we present a series of articles that address the challenges, as well as highlight some successes, in linking conservation and development in Latin America and Africa. These articles stem from a conference in 2010 (Bridging Conservation and Development in Latin America and Africa) organized by the University of Florida's Tropical Conservation Development Program, Center for African Studies, and Center for Latin American Studies. The conference sought to bridge academics and nonacademics, conservation and development, and theory and practice, especially across the contrasting historical, cultural, socioeconomic, political, and ecological trajectories of the two regions. The articles in this Special Issue represent the continuing dialogue and joint efforts initiated during the conference between scholars and practitioners, often bringing together researchers from Africa with those from Latin

\footnotetext{
${ }^{1}$ Tropical Conservation and Development Program, Center for Latin American Studies, University of Florida., ${ }^{2}$ Tropical Conservation and Development Program and Amazon Conservation Leadership Initiative, Center for Latin American Studies, University of Florida., ${ }^{3}$ Wildlife Conservation Network,

${ }^{4}$ Tropical Conservation and Development Program, Center for Latin American Studies, University of Florida
} 
America, for the kind of comparative analysis that is rare in the published literature on conservation and development.

To set the stage for these articles, we first briefly review the evolution of the dominant ideas framing conservation and development, in both theory and practice. We then present a conceptual framework based on some of the key themes emerging from the articles in this Special Feature, identifying pillars, or driving forces, which determine spaces for both friction and concurrence between conservation and development goals. Common themes emerging from Africa and Latin America include the importance of empowering local institutions; enhanced capacity of local and regional stakeholders through a recognition and validation of local knowledge systems and the creation of knowledge networks; the importance of understanding social and natural landscapes, history, contexts, and their evolution; as well as the complex role of economic and market forces in shaping opportunities for using market-based incentives to promote conservation and development. Taken together, the articles contribute to the recent efforts to advance conservation and development goals by emphasizing the identification of trade-offs and synergies (Kusters et al. 2006, Sayer 2009, Campbell et al. 2010, McShane et al. 2011). We aim to assimilate knowledge from past experiences, and to promote social learning among researchers and practitioners, particularly in the developing world, who are committed to the science of sustainability.

\section{EVOLUTION OF CONSERVATION AND DEVELOPMENT STRATEGIES IN THE DEVELOPING WORLD}

Until recently, efforts to achieve conservation and development goals were separate and sometimes at odds with one another, reflecting differences in the actors, power structures, and policy realms that underlie these (Adams et al. 2004). Initiatives to preserve natural areas, such as Yellowstone National Park in the western U.S., began in the 1870s alongside the beginning of development in the Industrial Revolution. While set-asides that are protected from undue human influence have continued to be part of the conservation lexicon, since World War II other strategies have arisen that stress the sustainable use of resources for human benefit, relying on scientific methods to improve efficiency, in parallel with the increasing emphasis on economic growth and efficiency in the post-war development world (Schmink and Jouve-Martín 2011). Before the 1970s the international development agenda focused on promoting economic growth via technology transfers, to increase agricultural productivity, and enhance infrastructure development (Richards 1985, Scott et al. 2011), supported with international loans that unfortunately were often poorly coordinated and at times conflicting with priorities identified by national institutions (Easterly 2007).

Initially, in developing countries, the approach to natural resource conservation was nature preservation (International
Union for the Conservation of Nature 1992, Dudley 2008); extensive areas were set aside as protected areas in the 1970s and 1980s, mostly to maintain biodiversity, with the support and funding of large global conservation organizations (Roe 2008). Rather than places to promote regional development (Brandon 1997), under this model, parks were to remain untouchable and presumably inalienable. With few exceptions, the exclusive goal of nature protection via fortress conservation models hindered traditional resource use by often unrecognized local communities who already inhabited most of these areas in Latin America and Africa. The adequacy of this command-and-control strategy was challenged by resistance from these communities, as resource use rights were curtailed, and livelihood activities were displaced from diversity-rich areas, typically towards rapidly expanding urban settlements (Agrawal and Redford 2006, Brockington et al. 2006, Brockington and Igoe 2006, Wilkie et al. 2006). These new territorial arrangements fueled tensions and led to conflicts among state agencies, local communities, and external actors (Schwartzman et al. 2000, Cernea and SchmidtSoltau 2006, McElwee 2010), and contributed to losses of both social and natural capital, with little enhancement of rural wellbeing or empowerment of local institutions (Chambers 1997, Schmidt-Soltau and Brockington 2007).

Increasingly linkages between development and conservation were recognized in the 1970s and 1980s, culminating in the formulation of the World Conservation Strategy led by the World Conservation Union (IUCN) and other institutions (for example, International Union for the Conservation of Nature et al. 1980). This influential document recognized the finiteness of natural resources, and the need for ensuring their sustainable use.

In an effort to reconcile environmental protection with the needs of otherwise displaced or disenfranchised people, buffer zones, in which local people were permitted to seek their livelihoods, were delimited around strictly protected areas. Although designed to facilitate the coexistence of humans and nature, the principal objective of those areas remained preservation of natural places and resources. More often than not, this model was perceived as yet another way for central governments to capture control of remote and vast territories without due consideration of local knowledge and traditional institutional arrangements for natural resource use (Neumann 1997). Resistance by local communities to such impositions, and the increasing recognition of indigenous and human rights during the 1970s and 1980s, set the stage for a new era of conservation that would more thoroughly integrate human benefits and biodiversity conservation.

This period saw parallel changes in development thinking and practice, and contributed new ideas and perspectives to conservationists, leading to novel, more integrated approaches to community-based conservation. As a result, there was a major shift towards the valorization, inclusion, and 
empowerment of local communities in rural development (Chambers 1994a, 1994b). This movement was triggered by growing critiques of top-down approaches to rural development that contributed little to poverty reduction because they left local people outside the process of defining development needs and agendas (Holling and Meffe 1996, United Nations Economic and Social Commission for Asia and the Pacific 2009). Participatory approaches to development emerged in several places in the 1970s, and spread in the 1980s, in Central America, Asia, and Africa (Freire 1970, Whyte 1991, Chambers 1994a, Chambers 1994b). They were embraced and championed by some conservationists seeking a more holistic framework and interested in increasing South-South collaboration and learning (Andrade 2010, Zimmermann and Smith 2011). Despite the limitations of many so-called participatory projects, experience in participatory development helped build social capital, and alternative ways of conducting research and managing projects, which has changed the social, scientific, and political agendas in the development arena (Hickey and Mohan 2004).

Among conservationists responding to calls for greater autonomy for local people, participatory approaches began to emphasize the knowledge and empowerment of local communities in decision making regarding the use and management of natural resources. The goal was to allow communities to contribute substantially towards decision making and agenda definition for all projects and policies that affected them (United Nations Economic and Social Commission for Asia and the Pacific 2009). Communitybased natural resource management initiatives flourished in Africa and Latin America under the participatory and bottomup perspectives brought by participatory development theory and practice.

Many recent efforts at addressing development and poverty challenges outside of protected areas emerged from discussions held during the Rio Summit of 1992. One was the emergence of the Integrated Conservation and Development Projects (ICDPs) approach to alleviating poverty and promoting sustainable development in biodiversity-rich areas (Franks and Blomley 2004). The rationale behind ICDPs was that since poverty was a leading cause of species extinction and loss of forest cover in biodiversity hotspots, initiatives to promote either conservation or development separately were doomed to failure (Alpert 1996, Sanderson and Redford 2003, Sanderson 2005). Therefore, ICDPs proposed to tackle the whole range of conservation and development needs and issues in an integrated local fashion. ICDPs facilitated the transfer of substantial funds from developed to less developed countries; their impacts are much debated (for reviews see Hughes and Flintan 2001, Wells et al. 2004, Sandker et al. 2009, Blom et al. 2010). With mixed results and high costs, and despite aspirations of participatory decision making,
ICDPs were sometimes criticized as authoritarian interventions from outside that were not based on negotiated common objectives, and did not adequately consider the visions and aspirations of local stakeholders (Robinson and Redford 2004, Sayer et al. 2007).

Another novel policy concept that emerged from the Rio Convention in 1992 was that of ecosystem services. The ecosystem services approach attempted to promote sustainable use by integrating the history and management of natural resources including water and land, across scales (Tallis et al. 2008, Pfund 2010). The Millennium Ecosystem Assessment (Millennium Ecosystem Assessment 2005) provided a much needed overarching framework to categorize and analyze ecosystem services, enabling policy makers to expressly address a key gap in natural resources valuation. Using this perspective, the value of biodiversity, for instance, was framed into a broader view that considered a wide range of attributes associated with natural and social systems. Although the emphasis on ecosystem services helped highlight the need for an integrated view of natural resource management based on multistakeholder perspectives across scales of space and time, its practical implementation remains a challenge in most places (but see Sunderlin and Thu 2005).

Another key policy shift in the 1990s was the emergence of neoliberal policies emphasizing privatization, markets, and small government. Efforts to decentralize resource management policy and devolve control of resources to local communities were undertaken in the developing world, often in direct response to the growing pressures of social movements and their advocates pushing for rights to land and resources by local and indigenous peoples (but see Ribot et al. 2006). Constitutional reforms, particularly in Latin America, formalized these novel policy arrangements and set the stage for local communities to realize the rights and responsibilities associated with stewardship of their own land and resources (Larson 2005, Pacheco 2005, Batterbury and Fernando 2006, Larson and Soto 2008, Somanathan et al. 2010). Meanwhile, a growing body of research demonstrated the role of local institutions in regulating resource use and overcoming the much feared tragedy of the commons (Hardin 1968, Dietz et al. 2003, Ostrom 2008). Novel approaches to resource management emerged, emphasizing the flexibility and environmental suitability of local institutions and their capacity for adaptive management and social learning (Berkes 1999, Stringer et al. 2006, Pahl-Wostl et al. 2007). Most of these experiments still remain to be tested in order to assess the impacts they have had on the social actors involved and the natural resource base, and to understand the elements that might facilitate replication of successes and social learning elsewhere (but see Plummer and Armitage 2007).

Combining the recognition of ecosystem services as explicit assets, and the growth of neoliberal policies favoring market- 
oriented strategies, led to the concept of payment for ecosystem services (PES). In other words, markets for ecosystem services could be used to promote sustainable natural resource use, and simultaneously contribute to improving rural livelihoods (Angelsen and Wunder 2003, Wunder 2005, Wunder et al. 2008). Proponents of this model argue that markets for these services would efficiently deal with the positive and negative externalities of the production of goods and services derived from natural resources (Ferraro and Kiss 2002). Market-based schemes based on PES (as well as on rewards or compensation payment schemes) were added to other economic incentives such as certification and conservation easements (Arrow et al. 2007, Ring et al. 2009). The current proposal to implement payments to reduce emissions from tropical deforestation and forest degradation (REDD+) represents the latest example of how the international community has considered market-based strategies to effectively combat global climate change (Angelsen 2011). To date, though, empirical evidence of the impacts of market-based initiatives is still lacking (e.g., certification: Wunder 2007, Blackman and Rivera 2010, PES: Milder et al. 2010, Pattanayak et al. 2010, but see Polaski and Segerson 2009).

Taking stock of the past four decades suggests that conservation and development strategies must be integrated in some fashion, involving and empowering local communities, and based on a holistic system of knowledge and valuation of natural resources. The conditions for the successful synergy between conservation and development, however, remain challenging to identify and analyze.

\section{A FRAMEWORK TO UNDERSTAND BRIDGES BETWEEN CONSERVATION AND DEVELOPMENT}

We propose a conceptual framework articulated around key factors that underpin trade-offs between conservation and development. The articles in this Special Issue illustrate some of these key factors, their interactions, and their impact on conservation and development. The focus on these factors is intended to highlight some of our findings, not to disregard the inherent complexity we are unable to capture in our framework. Decisions made at one time and place affect other places at other times through complex nonlinear and unpredictable linkages (e.g., globalization; Boyce 2008), and our simplified framework does not address these complex linkages. We also recognize that achieving conservation and development synergies is constrained by the prevailing economic models that advocate increasing economic growth without regard for a finite natural resource base (Stiglitz 2006), and the challenging and uncertain effects of global climate change (increased variability and uncertainty; Parry et al. 2009) on future livelihood systems. We nevertheless argue that tensions between conservation and development provide opportunities to negotiate trade-offs and identify synergies. It is only by accepting and recognizing these trade-offs that society can construct a strong foundation towards sustainability (Sunderland et al. 2008, Campbell et al. 2010).

We developed the conceptual framework to structure and facilitate the analysis of the conditions under which conservation and development goals merge synergistically, or can otherwise clash. The goals of sustainable natural resource management (NRM) are at the core of this overlap. We are interested in learning about NRM strategies that balance ecological sustainability and human development needs. We propose that the dynamic and evolving struggles between conservation and development are affected by a set of six broad factors (Figure 1): characteristics of natural resources; interactions of social actors; governance and participation; politics; information exchange; and economics. We will refer to these factors as pillars because their relationships define a potential foundation for building enduring synergies between conservation and development.

Fig. 1. Conservation and development conceptual framework.

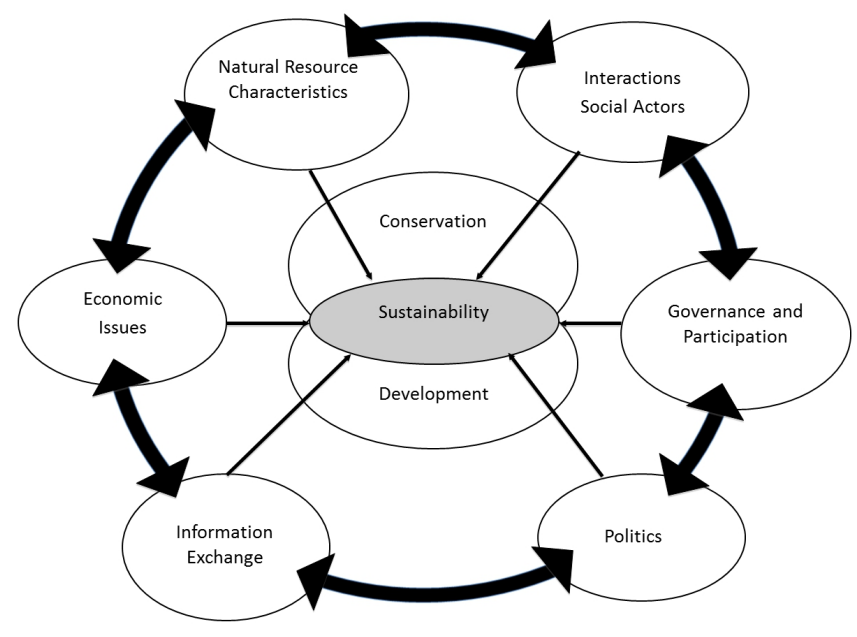

Each of the six pillars supporting conservation and development actually represent numerous complex concepts that could be unpacked further, but we will limit ourselves to a brief overview. The first, natural resource characteristics, includes the types of resources, the natural services they provide, and the kinds and intensities of use, stress, and disturbance regimes to which they are subjected. Different ecosystems provide different resources (e.g., fish, timber, or water) that have different uses and present a range of management responses. These ecosystems also provide a wide array of ecosystem services, such as water filtration and carbon sequestration, for which management strategies could be appropriately tailored. Disturbance regimes also vary, including but not limited to fire, invasive species, or resource 
harvesting. As the drivers and consequences of each disturbance regime also vary, management must be adapted to these unique contexts.

Interactions of social actors represent the second pillar. They include the negotiations among government agencies and individual citizens and resource users, as well as nongovernmental local, national, and international organizations. These actors choose from a range of natural resource management strategies and are subject to constraints (e.g., information, technology, access to resources), belief systems, knowledge, and norms that differ as widely as the cultures in which they are embedded. Social actors are both agents and objects of change, and each of these actors is organized differently, with diverse levels of power and resources, at various scales, leading to interactive networks that can themselves become discrete stakeholder groups in particular NRM strategies. To understand social actors, we must also examine how their characteristics change due to dynamic micro- and macro-processes, such as histories and drivers of displacement and migration, power distribution, and access to resources, as they intersect with individual histories.

Another key factor affecting the balance between environmental conservation and human development revolves around governance and participation. We use the term governance to encompass various formal and informal institutions and policies that affect land and natural resource tenure, natural resource access and use rights, human rights, provision of and access to social services, decision making at varying scales, as well as the transparency, accountability, and enforcement of NRM policies. Participatory governance issues affect how social actors with initially divergent conservation and development objectives can negotiate tradeoffs and make possible or preclude options for sustainable development.

Politics, which are closely linked to but distinct from governance, profoundly influence the identification of synergies between, and the implementation of, environmental conservation and sustainable development. Politics reflect power relationships and their dynamics (i.e., power over whom and over what; Scott et al. 2011). Rather than emphasizing policies themselves, politics shape the enabling environment for these policies. As such, politics encapsulate issues of power, participation, conflicts, information, and historical legacies. To properly understand how politics influence the conservation-development nexus, scholars often use a political ecology lens, which ties ecology and natural resource management outcomes to political and economic processes occurring at distinct spatial and temporal scales (Zimmerer and Bassett 2003).

Another pillar supporting conservation and development is information exchange, which empowers different social actors, and affects politics and governance, ultimately shaping
NRM outcomes. By information exchange we mean both scientifically generated and traditional knowledge, including the ability to collect, analyze, and interpret data, and finally the communication technologies used to share knowledge among social actors. Information exchange is, and has always been, associated with power, and should be at the heart of our individual and collective decision making capacity. Information sharing and platforms for mutual learning can help diverse stakeholders involved in conservation and development initiatives improve dialogue and shared understanding (Bessette 2004). Information can enable social actors to participate in NRM processes from which they were previously excluded, as well as to develop innovative ways for documenting and sharing activities and projects outcomes, such as videos, websites, and publications (Bessette 2004). While technology provides the potential to process and distribute information, inequalities hinder the application of information to decision making. Information availability is not synonymous with accessibility, nor can information sharing or access alone ensure equitable or improved outcomes for conservation and development initiatives.

The sixth and final pillar in our model is economics. Formal and informal markets, as well as international investments including aid and financial flows, shape the context within which trade-offs between conservation and development are made explicit. A number of economic tools, mostly various sorts of incentives, have been proposed to encourage positive development and conservation outcomes, and continue to be an active area in which research is needed. The design of specific economic tools and policies is greatly affected by different conceptualizations of the relationships between economics and the environment. Policies need to question the assumption that every social actor strives to maximize economic and financial benefits (Bowles et al. 2003, Bowles and Gintis 2009), and take into account the somewhat invisible costs and benefits of natural resource use by local communities for their incorporation into fair policy making (Shackleton et al. 2007).

We acknowledge that the conceptual framework we present is a simplification of the complex and messy reality of conservation and development. Although each of the six broad factors we describe affects synergies between environmental conservation and human development individually, the strongest influence is derived from the often nonlinear interactions among them. Clearly, this level of interactive complexity is not depicted in our diagram, but visual artlessness should not be mistaken for conceptual simplicity in seeking to explore the bridges between conservation and development. The framework highlights some of the important findings contained in this volume regarding the importance of meaningful and fair negotiation among social actors, participatory and adaptive governance, pro-poor political strategies and information exchange, and analysis of markets 
as tools to promote synergies in sustainable natural resource management in different regions of the developing world.

\section{OVERVIEW OF THIS SPECIAL ISSUE: BUILDING BRIDGES, TURNING POINTS FOR FUTURE ACTION}

The overarching theme of this collection of articles is the concept of bridges as a key metaphor: bridges as commonalities between disparate cultural and geographic contexts, as synergies between the goals of conservation and development, as conceptual links between diverse regions, which allow us to compare lessons learned, and finally, as a means to connect science and policy, and policy and learning. The articles share a comparative approach, examining cases from Latin America and Africa, with the goal of understanding how context and geography create diverse spaces for conservation and development by shaping the specific architecture of the pillars described in our framework. By building upon and sharing their accumulated experiences in Latin America and Africa, the authors included in this Special Issue consider how interaction among social actors, governance and participation, politics, information exchange, and economics intersect and interact to inform conservation and development challenges, strategies, and outcomes. The analyses provided in each article demonstrate common paths and important divergences in the two regions.

The articles by Mulale et al. and Podkul et al. take a closer look at historical processes in Latin America and Africa that provide favorable or unfavorable contexts for institutional development and conservation and development outcomes. Both articles argue that in Latin America, social movements have played a critical role in mobilizing disparate and often marginalized groups to gain access to and control over land and natural resources, with substantial positive impacts on conservation, development, and empowerment. In contrast, the development and organization of grassroots social movements in Africa has been limited, leading Mulale et al. and Podkul et al. to contrast how societies have mobilized in the two regions around conservation and development issues, and how these varying historical, socio-cultural, and political trajectories affect not only the success of conservation and development initiatives, but also the overall well-being of resource-dependent people.

Mulale et al. examine the historical underpinnings of the decentralization and devolution of natural resource management to local communities in Mexico and Namibia. By employing the concept of critical junctures (Capoccia and Kelemen 2007) along with the adaptive cycle model, they posit that enduring institutional changes in social-ecological systems result from pivotal moments in history. They apply this idea to the processes of resource governance reform in Mexico and Namibia, contrasting Mexico's historically grounded grassroots impetus for land reform with a more recent top-down approach to decentralization in Namibia.
They argue that broad-based social mobilization, the ability to merge traditional authorities and institutions into new forms of community-based governance, in concert with state support of community-based natural resource management, are crucial in sustaining resource governance reforms and the continued evolution of community-based natural resource management. Mulale et al.'s article provides an example of how participatory governance, as a foundational pillar, influences the success of conservation and development outcomes, in this case providing institutional structures for communities to participate in, and benefit from, conservation initiatives.

Podkul et al. examine the ways in which the nexus between national development politics and natural resources produces or mitigates vulnerability among diverse social actors who rely upon those resources in the Andes of South America and in southern Africa. The authors demonstrate how historical and current restrictions on natural resource access within the two regions increase vulnerability and marginalization of resource-dependent people, specifically through the creation of the UN Biosphere Reserve Yasuní National Park in Ecuador (1989) and the Kalahari Gemsbok Park (1931). Natural resource access is constrained by both historical and socioenvironmental processes, precipitating diverse local responses that range from acquiescence and accommodation to violent conflict. Podkul et al. propose that in their Latin American example, a tradition of social mobilization and protest against resource extraction and access by outsiders has created a role for social movements in mitigating their vulnerability. In contrast, limited social mobilization related to natural resource access in their southern Africa example, in combination with other historical, cultural, and political factors, has limited the ability of resource-dependent populations to address vulnerability. Podkul et al.'s article demonstrates the critical role of natural resource politics, including conservation fortress visions and resource extractivism in the name of national interests, in curtailing positive development and conservation outcomes. However, they conclude by offering a glimmer of hope that social movements can play an important part in effecting change, and possibly even in diminishing the acuteness of certain vulnerabilities.

Contributions by Constantino et al. and Burford et al. provide concrete examples of the potential for social empowerment to foster environmental conservation. Specifically, these articles illustrate how partnerships, alliances, and exchange of information between a diversity of social actors, including scientists, indigenous, and other communities, foster ownership of NRM and enable knowledge sharing and intercultural learning. These articles describe obstacles and constraints encountered while reconciling social learning by different stakeholders, local empowerment, and natural resource conservation, thereby providing opportunities for the exchange of experiences and learning between individuals, communities, and countries in Africa and Latin America. 
Constantino et al. compare three wildlife monitoring systems used on indigenous lands and sustainable development reserves in the Brazilian Amazon, and the Caprivi Conservancy in Namibia. They analyze strategies and conditions that fostered empowerment at the individual and community levels. In Namibia, the possibility of marketing valuable wildlife, as well as the rights of communities to manage and market game species, enabled economic community empowerment that was not achieved in Brazil where wildlife trade is banned by national and international regulations. The authors identify this situation as a challenge to be tackled in bridging the gap between conservation and development in the Brazilian Amazon, since environmental conservation that brings social and political empowerment combined with the generation of economic benefits is more prone to be successful in the long term (Hall 2007). In spite of the lack of economic benefits in the Brazilian cases, increased local participation and strategies for exchange and ownership of information on resource management were important factors that promoted both individual and community empowerment. This article demonstrates how key elements such as information exchange (e.g., social learning and empowerment processes), natural resource characteristics (e.g., resource value), and economics (e.g., incentives and benefits from wildlife conservation) can combine to facilitate synergistic relationships between wildlife conservation and rural development.

Burford et al. discuss the formalization and institutionalization of intercultural education for fostering sustainable development, comparing two experiences of university and secondary educational systems in Mexico and Tanzania: the Intercultural Maya University of Quintana Roo and the Noonkodin Secondary School of Tanzania. The authors explore the linkages between participation theory and intercultural education, advocating for experiences that can empower local communities and at the same time provide grounds for the co-creation of knowledge between indigenous people and western scientists and communities, and ultimately scale up to institutions and political entities (Gibbons et al. 1994). This co-creation of knowledge is an example of transdisciplinary science that reaches beyond academia and has the potential to transform societal views of knowledge production and sharing, towards development that is inclusive of cultural diversity and thus more legitimate (Brechin et al. 2002). In both cases the authors explore the depth and breadth of local participation, suggesting that the adoption of an evaluation lens, built on the principles of participatory monitoring and evaluation, and through values-based indicators, is pivotal for reinforcing cultural ties to natural resources and empowering a broader set of social actors to participate in management. This evaluation process would also enable comparisons between diverse experiences in intercultural education for sustainable NRM. Returning to the importance of institutions and policies supporting grassroots conservation and development, the greatest difference found between the Mexican and Tanzanian cases is how intercultural education is validated and disseminated through the different scales of governance, from regional to national. In Tanzania, a history of blocking discussions of ethnicity and indigenous knowledge constrained the mainstreaming of intercultural education. In Mexico, in contrast, official support from state and federal policies and institutions helped integrate the intercultural approach into formal education in a transformational effort that reaches society at large. Buford et al.'s contribution is an example of the central role of information exchange (including knowledge production and valuation of traditional forms of knowledge) in laying the foundation for a sustainable vision that is inclusive as well as adaptive.

Bustamante et al. examine the role of information and social actors within scientific networks in Brazil, arguing that such regional networks provide important institutional platforms for learning and action for conservation and development, yet their potential to affect public policy remains untapped. The complexity and urgency of current environmental change, they argue, position these networks so they can both adapt and respond to the new political realities that influence scientific endeavors. By focusing on the merits, obstacles, facilitating factors, and lessons learned from efforts to create regional networks, Bustamante et al.'s case studies illustrate how regional scientific networks are currently underutilizing their potential to affect public policy, especially given their proximity to decision making processes. Social actors are able to form bonds of trust through these networks, wherein mutual learning takes place and knowledge is transferred. They argue that these linkages extend to the local and national communities that host and surround them. Broad-based participation by social actors in the formulation of research agendas, as well as their willingness to accommodate nonscientific expectations, are distinct features of these networks. Beyond information exchange itself, which is a pivotal factor in several articles in this Special Feature, Bustamante et al. illustrate the importance and potential role of specific social actors, in this case regional scientific communities, in bringing information to conservation and development decision making.

Cardoso et al. investigate the emergence and importance of market-based mechanisms, specifically roundtables (fora where representatives of industrial and governmental sectors and members of civil society, including international institutions, discuss and negotiate standards and other aspects of sustainability) for promoting conservation and development in Latin America and Africa. They posit that the proliferation of roundtables, which often result in new certification programs, represents a novel nonstate governance system aimed at influencing all elements of product supply 
chains. Their paper reviews the emergence of these roundtables and the challenges they face, as well as their theoretical, practical, and empirical significance in Brazil. It draws from case studies on soy, biofuel, cattle, and forests. The authors acknowledge the recent shift away from government regulation toward processes that encourage partnerships between state and private actors working jointly for the protection of the environment. These multistakeholder initiatives encourage dialogue among participants and promote the setting and monitoring of social and environmental standards, which often lead to the certification of good practices. The authors suggest that the development of roundtables, by providing fora for the involvement of a wide range of stakeholders, has modified the power relations among them, and provided a mechanism for learning and engagement. They conclude by admitting that although roundtables cannot be expected to make the relations in a capitalist society completely transparent, they can aid in making social and environmental dimensions part of the mechanisms of market functioning. This article demonstrates a mutual role for markets and participatory governance in forging new incentives for conservation that also promote economic development.

\section{CONCLUSION AND THE WAY FORWARD}

The articles presented in this special issue help illustrate and advance some of the potential bridges to address the challenges and opportunities for the design and implementation of synergistic conservation and development strategies underlying sustainability in the $21^{\text {st }}$ century. The global environmental and development policy context is continually evolving. The separate domains of conservation and development prior to the 1970s have developed into a more holistic understanding of human-environment relationships as mutually linked, for better or worse. This ideological evolution is illustrated by the "green economy" theme for the Rio +20 conference, which argues for further equity and stewardship for future generations in response to the climate, food security, and economic crises (Ocampo 2011).

As new challenges to the integration of conservation and development arise, others persist mostly unchanged. Many countries continue to struggle with fragile political institutions (Sanderson 2005, Garnett et al. 2007, Karsenty and Ongolo, in press), unclear and insufficient local participation in decision making processes, and lack of social safeguards to overcome ambiguous property rights (Agrawal et al. 2008, Lawlor et al. 2010). Furthermore, food security and human health are increasingly threatened by climate change, with which resource-dependent communities are hard-pressed to cope. Lack of social services and investment in human capital, due to neoliberal austerity programs, reinforce people's marginalization and undermine their ability to adopt long-term strategies for conservation and sustainable development.
In light of our increased understanding of the complexity of conservation and development trade-offs and synergies, researchers and practitioners are also aware that there are no silver bullets. Any strategy must be articulated into an integrated framework that fully considers checks and balances for fair and enduring solutions for society at large. Given the multiple threats to forests in the tropics, sustainable solutions must address a variety of factors such as unplanned land conversions due in part to competing land use goals and views, and must promote adequate engagement of, and benefits to, multiple stakeholder groups, as well as proper resource valuation.

The articles in this Special Issue highlight the complexity of conservation and development strategies and outcomes, and the importance of stakeholder interactions, politics, participatory governance, information exchange, and economics in both exacerbating challenges, while at the same time potentially creating opportunities to advance toward integrating conservation and development goals. Progress often is incremental, rather than structural, but we must be aware that the environmental, economic, and political conditions affecting these activities are rapidly and constantly changing.

The social contract requires a change in direction, and now more than ever, consistent investments to strengthen human and social capital. Social actors and institutions must better grasp the impacts of policies and other interventions, revisit mistakes to renew their knowledge base, and adapt accordingly to achieve their goals. This collection of articles argues for a central role of social actors in interacting to forge synergies between conservation and development by exchanging information and sharing power and knowledge. To sustainably integrate conservation and development, we need to recognize the power of intercultural knowledge sharing, local participation in monitoring and resource management, and research networks and social movements in providing access to information and decision making processes, and in creating innovative rights-based and marketbased incentives. These diverse strategies, in essence, help to creatively balance the costs and benefits for all stakeholders to address the challenges of sustainable development, which require coordinated efforts by governmental agencies, academic institutions, the private sector, and civil society.

Even then, more challenges lie ahead. Identifying the next steps toward sustainability requires continual evaluation and adaptation of conservation and development strategies, as well as careful analyses of complex interacting factors within linked social-ecological systems, especially given the host of uncertainties related to climate change and the volatile global economy. We may create our path forward by learning from one another's experience. As we hope this Special Issue illustrates, diverse, yet sometimes parallel experiences in Latin 
America and Africa offer key lessons that not only bridge the two regions, but also strengthen the bridges between conservation and development solutions.

Responses to this article can be read online at: http://www.ecologyandsociety.org/vol17/iss2/art17/ responses/

\section{Acknowledgments:}

Publication of this article was funded in part by the University of Florida Open-Access Publishing Fund and by the Latin American Students Association- LASA.

\section{LITERATURE CITED}

Adams, W. M., R. Aveling, D. Brockington, B. Dickson, J. Elliot, J. Hutton, D. Roe, B. Vira, and W. Woolmer. 2004. Biodiversity conservation and the eradication of poverty. Science 306:1146-1149. http://dx.doi.org/10.1126/science.10 $\underline{97920}$

Agrawal, A., and K. H. Redford. 2006. Poverty, development and biodiversity conservation: shooting in the dark? Wildlife Conservation Society Working Paper Number 26. Wildlife Conservation Society, New York, New York, USA.

Agrawal, A., A. Chhatre, and R. Hardin. 2008. Changing governance of the world's forests. Science 320:1460-1462. http://dx.doi.org/10.1126/science.1155369

Alpert, P. 1996. Integrated conservation and development projects. BioScience 46:845-855. http://dx.doi.org/10.2307/13 $\underline{12970}$

Andrade, M. 2010. South-south cooperation: the same old game or a new paradigm? Pages 25-27 in Poverty in focus. International Poverty Centre for Inclusive Growth. Poverty Practice, Bureau for Development Policy, United Nations Development Program. Brasilia.

Angelsen, A., and S. Wunder. 2003. Exploring the forestpoverty link: key concepts, issues and research implications. CIFOR Occasional Paper 40. Center for International Forestry Reserach (CIFOR), Bogor, Indonesia

Angelsen, A. 2011. Policies for reduced deforestation and their impact on agricultural production. Proceedings of the National Academy of Sciences: 107:19639-19644. [online] URL: http: //dx.doi.org/10.1073/pnas.0912014107

Arrow, K., B. Bolin, R. Costanza, P. Dasgupta, C. Folke, C. S. Holling, B. Jansson, S. Levin, K. Mäler, C. Perrings, and D. Pimentel. 2007. Economic growth, carrying capacity, and the environment. Science 268:520-521. http://dx.doi.org/10.1 $\underline{126 / \text { science. } 268.5210 .520}$
Barrett, C., A. J. Travis, and P. Dasgupta. 2011. On biodiversity conservation and poverty traps. Proceedings of the National Academy of Sciences 108:13907-13912. http://d x.doi.org/10.1073/pnas.1011521108

Batterbury, S. P. J., and J. L. Fernando. 2006. Rescaling governance and the impacts of political and environmental decentralization: an introduction. World Development 34:1851-1863. http://dx.doi.org/10.1016/j.worlddev.2005.11.019

Berkes, F. 1999. Sacred ecology. Taylor and Francis, New York, USA.

Bessette, G. 2004. Involving the community. A participatory guide to development communication. Southbound, Penang and International Development Research Centre (IDRC), Ottawa, Canada.

Blackman, A., and J. Rivera. 2010. Environmental certification and the Global Environment Facility: STAP advisory document. Prepared on behalf of the Scientific and Technical Advisory Panel (STAP) of the Global Environment Facility (GEF). Washington, D.C., USA.

Blom, B., T. Sunderland, and D. Murdiyarso. 2010. Getting REDD to work locally: lessons learned from integrated conservation and development projects. Environmental Science and Policy 13:164-172. [online] URL: http://dx.doi.o rg/10.1016/j.envsci.2010.01.002

Bowles, S., J. K. Choi, and A. Hopfensitz. 2003. The coevolution of individual behaviors and social institutions. Journal of Theoretical Biology 223:135-147. http://dx.doi.org /10.1016/S0022-5193(03)00060-2

Bowles, S., and H. Gintis. 2009. Beyond enlightened selfinterest: social norms, other-regarding preferences, and cooperative behavior. Pages 57-78 in S. A. Levin, editor. Games, groups, and the global good. Springer Series in Game Theory. Springer, Berlin and Heidelberg, Germany. [online] URL: http://dx.doi.org/10.1007/978-3-540-85436-4 3

Boyce, J. K. 2008. Is inequality bad for the environment? Pages 267-288 in R. C. Wilkinson, and W. R. Freudenburg, editors. Equity and the environment. Series Research in Social Problems and Public Policy. Elsevier, Amsterdam, Netherlands.

Brandon, K. 1997. Policy and practical considerations in landuse strategies for biodiversity conservation. Pages 90-114 in R. Kramer, C. van Schaik, and J. Johnson, editors. Last stand: protected areas and the defense of tropical biodiversity. Oxford University Press, Oxford, UK.

Brechin, S. R., P. R. Wilshusen, C. L. Fortwangler, and P. C. West. 2002. Beyond the square wheel: toward a more comprehensive understanding of biodiversity conservation as 
social and political process. Society and Natural Resources 15:41-64. http://dx.doi.org/10.1080/089419202317174011

Brockington, D., and J. Igoe. 2006. Eviction for conservation: a global overview. Conservation and Society 4:424-470.

Brockington D, J. Igoe, and K. Schmidt-Soltau. 2006. Conservation, human rights, and poverty reduction. Conservation Biology 20:250-252. [online] URL: http://dx.do i.org/10.1111/j.1523-1739.2006.00335.x

Campbell, B. M., J. A. Sayer, and B. Walker. 2010. Navigating trade-offs: working for conservation and development outcomes. Ecology and Society 15(2):16. [online] URL: http: //www.ecologyandsociety.org/vol15/iss2/art16/

Capoccia, G., and R. D. Kelemen. 2007. The study of critical junctures: history, narratives, and counterfactuals in historical institutionalism. World Politics 59:341-369. http://dx.doi.org /10.1017/S0043887100020852

Carter, L. J. 1980. Marriage of conservation and development. Science 207:1328-1329.

Cernea, M. M., and K. Schmidt-Soltau. 2006. Poverty risks and national parks: policy issues in conservation and resettlement. World Development 34:1808-1830. [online] URL: http://dx.doi.org/10.1016/j.worlddev.2006.02.008

Chambers, R. 1994a. The origins and practice of participatory rural appraisal. World Development 22:953-969. http://dx.doi. org/10.1016/0305-750X(94)90141-4

Chambers, R. 1994b. Participatory rural appraisal (PRA): analysis of experience. World Development 22:1253-1268. http://dx.doi.org/10.1016/0305-750X(94)90003-5

Chambers, R. 1997. Whose reality counts? ITDG Publishing, London, UK.

Clark, W. C., and N. M. Dickson. 2003. Sustainability science: the emerging research program. Proceedings of the National Academy of Sciences 100:8059-8061. http://dx.doi.org/10.1073/ pnas. 1231333100

Dietz, T., E. Ostrom, and P. C. Stern. 2003. The struggle to govern the commons. Science 302:1907-1912. [online] URL: http://dx.doi.org/10.1126/science.1091015

Dudley, N., editor. 2008. Guidelines for applying protected area management categories: final draft of revised guidelines. International Union for the Conservation of Nature, Gland, Switzerland.

Easterly, W. R. 2007. The white man's burden: why the West's efforts to aid the rest have done so much ill and so little good. Oxford University Press, Oxford, UK.

Ferraro, P. J., and A. Kiss. 2002. Direct payments to conserve biodiversity. Science 298:1718-1719. [online] URL: http://dx. doi.org/10.1126/science.1078104
Fitzgerald, L. A., and A. L. Stronza. 2009. Applied biodiversity science: bridging ecology, culture, and governance for effective conservation. Interciencia 34:563-570.

Franks, P., and T. Blomley. 2004. Fitting ICD into a project framework: the CARE experience. Pages 77-97 in T. O. McShane, and M. P. Wells, editors. Getting biodiversity projects to work: towards more effective conservation and development. Columbia University Press, New York, USA.

Freire, P. 1970. Pedagogy of the oppressed. Continuum, New York, USA.

Garnett, S., J. Sayer, and J. DuToit. 2007. Improving the effectiveness of interventions to balance conservation and development: a conceptual framework. Ecology and Society 12(1):2. [online] URL: http://www.ecologyandsociety.org/vol12/ iss $1 /$ art $2 /$

Gibbons, M., C. Limoges, H. Norwotony, S. Schwarzman, P. Scott, and M. Trow. 1994. The production of knowledge: the dynamics of science and research in contemporary societies. Sage, London, UK.

Hall, A. 2007. Extractive reserves: building natural assets in the Brazilian Amazon. Pages 151-180 in J. K. Boyce, S. Narain, and E. A. Stanton, editors. Reclaiming nature: environmental justice and ecological restoration. Anthem Press, London, UK. http://dx.doi.org/10.7135/UPO97818433 $\underline{13465.007}$

Hardin, G. 1968. Tragedy of the commons. Science 162:1243-1248. http://dx.doi.org/10.1126/science.162.3859.1243

Hickey, S., and G. Mohan, editors. 2004. Participation: from tyranny to transformation. Zed Books, London, UK.

Holling, C. S., and G. K. Meffe. 1996. Command and control and the pathology of natural resource management. Conservation Biology 10:328-337. [online] URL: http://dx.do i.org/10.1046/j.1523-1739.1996.10020328.x

Hughes, R., and F. Flintan. 2001. Integrating conservation and development experience: a review and bibliography of the ICDP Literature. International Institute for Environment and Development (IIED), London, UK.

International Union for the Conservation of Nature (IUCN). 1992. Caracas action plan. Declaration and conclusions of the IVth World Congress on National Parks and Protected Areas, Caracas, Venezuela. IUCN Program on Protected Areas. Commission on National Parks and Protected Areas (CNPPA), Gland, Switzerland.

International Union for the Conservation of Nature, United Nations Environemnt Program, and World Wildlife Fund. 1980. World conservation strategy: living resource conservation for sustainable development. Gland, Switzerland. 
Karsenty, A., and S. Ongolo. In press. Can "fragile states" decide to reduce their deforestation? The inappropriate use of the theory of incentives with respect to the REDD mechanism. Forest Policy and Economics.

Keene, M., and A. S. Pullin. 2011. Realizing an effectiveness revolution in environmental management. Journal of Environmental Management 92:2130-2135. http://dx.doi.org/ 10.1016/j.jenvman.2011.03.035

Kusters, K., R. Achdiawan, B. Belcher, and M. Ruiz Pérez. 2006. Balancing development and conservation? An assessment of livelihood and environmental outcomes of nontimber forest product trade in Asia, Africa, and Latin America. Ecology and Society 11(2):20. [online] URL: http://www.eco logyandsociety.org/vol11/iss2/art20/

Larson, A. M. 2005. Democratic decentralization in the forestry sector: lessons learned from Africa, Asia and Latin America. Pages 32-62 in C. J. P. Colfer, and D. Capistrano, editors. The politics of decentralization: forests, power and people. Earthscan, London, UK.

Larson, A. M., and F. Soto. 2008. Decentralization of natural resource governance regimes. Annual Review of Environment and Resources 33:213-239. http://dx.doi.org/10.1146/annurev. environ.33.020607.095522

Lawlor, K., E. Weinthal, and L. Lander. 2010. Institutions and policies to protect rural livelihoods in REDD plus regimes. Global Environmental Politics 10:1-11. [online] URL: http:// dx.doi.org/10.1162/GLEP_a_00028

McElwee, P. D. 2010. Resource use among rural agricultural households near protected areas in Vietnam: the social costs of conservation and implications for enforcement. Environmental Management 45:113-131. http://dx.doi.org/10 $.1007 / \mathrm{s} 00267-009-9394-5$

McShane, T. O., P. D. Hirsch, R. C. trung, A. N. Songorwa, A. Kinxig, B. Montefelli, D. Mutekanga, H. van Thang, J. L. Dammert, M. Pulgar-Vidal, M. Welch-Devine, J. P. Brosius, P. Coppolillo, and S. O'Connor. 2011. Hard choices: making tradeoffs between biodiversity conservation and human wellbeing. Biological Conservation 144:966-972. http://dx.doi.or g/10.1016/j.biocon.2010.04.038

Milder, J. C., S. Scherr, and C. Bracer. 2010. Trends and future potential of payment for ecosystem services to alleviate rural poverty in developing countries. Ecology and Society 15(2):4. [online] URL: http://www.ecologyandsociety.org/vol15/iss2/ art4/

Millennium Ecosystem Assessment. 2005. Ecosystems and human well-being: a framework for assessment. Island Press, Washington, D.C., USA.
Minteer, B., and T. Miller. 2011. The new conservation debate: ethical foundations, strategic trade-offs, and policy opportunities. Biological Conservation 144:945-947. http://d x.doi.org/10.1016/j.biocon.2010.07.027

Nelson, E., G. Mendoza, J. Regetz, S. Polasky, H. Tallis, D. R. Cameron, K. Ma Chan, G. C. Daily, J. Goldstein, P. M. Kareiva, E. Londsorf, R. Naidoo, T. H. Ricketts, and M. R. Shaw. 2009. Modeling multiple ecosystem services, biodiversity conservation, commodity production, and tradeoffs at landscape scale. Frontiers in Ecology and Environment 7:4-11. http://dx.doi.org/10.1890/080023

Neumann, R. P. 1997. Primitive ideas: protected area buffer zones and the politics of land in Africa. Development and Change 28:559-582. [online] URL: http://dx.doi.org/10.1111 /1467-7660.00054

Ocampo, J. A. 2011. The macroeconomics of the green economy. Pages 16-39 in The transition to a green economy: benefits, challenges and risks from a sustainable development perspective. Report by a panel of experts to second preparatory committee meeting for United Nations Conference on Sustainable Development prepared under the direction of Division for Sustainable Development, United Nations Department of Economic and Social Affairs (UN-DESA) United Nations Environment Programme, UN Conference on Trade and Development, New York, USA.

Oldekop, J. A., A. J. Bebbington, and H. F. Preziosi. 2010. Understanding the lessons and limitation of conservation and development. Conservation Biology 24:461-469. http://dx.doi. org/10.1111/j.1523-1739.2010.01456.x

Ostrom, E. 2008. The challenge of common-pool resources. Environment 50:8-20. http://dx.doi.org/10.3200/ENVT.50.4.8-21

Pacheco, P. 2005. Decentralization of forest management in Bolivia: who benefits and why? Pages 166-183 in C. Colfer, and D. Capistrano, editors. The politics of decentralization: forests, people and power. Earthscan, London, UK.

Pahl-Wostl, C., J. Sendzimir, P. Jeffrey, J. Aerts, G. Berkamp, and K. Cross. 2007. Managing change toward adaptive water management through social learning. Ecology and Society 12 (2):30. [online] URL: http://www.ecologyandsociety.org/vol12/ iss $2 / \operatorname{art} 30 /$

Parry, M., N. Arnell, P. Berry, D. Dodman, S. Fankhauser, C. Hope, S. Kovats, R. Nicholls, D. Satterthwaite, R. Tiffin, and T. Wheeler. 2009. Assessing the costs of adaptation to climate change: a review of the UNFCCC and other recent estimates. International Institute for Environment and Development and Grantham Institute for Climate Change, London, UK.

Pattanayak, S. K., S. Wunder, and P. J. Ferraro. 2010. Show me the money: do payments supply environmental services in 
developing countries? 2010. Review of Environmental Economics and Policy 4:254-274. http://dx.doi.org/10.1093/reep/ $\underline{\text { req006 }}$

Pfund, J. L. 2010. Landscape-scale research for conservation and development in the tropics: fighting persisting challenges. Current Opinion in Environmental Sustainability 2010:117-126. http://dx.doi.org/10.1016/j.cosust.2010.03.002

Plummer, R., and D. Armitage. 2007. A resilience-based framework for evaluating adaptive co-management: linking ecology, economics and society in a complex world. Ecological Economics 61:62-74. http://dx.doi.org/10.1016/j.e colecon.2006.09.025

Polaski, S., and K. Segerson. 2009. Integrating ecology and economics in the study of ecosystem services: some lessons learned. Annual Review of Resource Economics 1:409-434. http://dx.doi.org/10.1146/annurev.resource.050708.144110

Raudsepp-Hearne, C., G. D. Peterson, M. Tengo, E. M. Bennett, T. Holland, K. Benessaiah, G. K. MacDonald, and L. Pfeifer. 2010. Untangling the environmentalist's paradox: why is human well-being increasing as ecosystem services degrade? BioScience 60:576-589. http://dx.doi.org/10.1525/b io.2010.60.8.4

Ribot, J. C., A. Agrawal, and A. M. Larson. 2006. Recentralizing while decentralizing: how national governments reappropriate forest resources. World Development 34:1864-1886. http://dx.doi.org/10.1016/j.worlddev.2005.11.020

Richards, P. 1985. Indigenous agricultural revolution: ecology andfood production in West Africa. Hutchinson Press, Boulder, Colorado, USA.

Ring, I., M. Dreschler, A. J. A. van Teffelen, S. Irawan, and O. Venter. 2009. Biodiversity conservation and climate mitigation: what role can economic instruments play? Current Opinions in Environmental Sustainability 2:1-9.

Robinson, J. G., and K. H. Redford. 2004. Jack of all trades, master of none: inherent contradictions among ICDP approaches. Pages 1-34 in T. O. McShane, and M. P. Wells, editors. Getting biodiversity projects to work: towards more effective conservation and development. Columbia University Press, New York, USA.

Roe, D. 2008. The origins and evolution of the conservationpoverty debate: a review of key literature, events, and policy processes. Oryx 42:491-503. http://dx.doi.org/10.1017/S0030 $\underline{605308002032}$

Roe, D., and J. Elliott. 2004. Poverty reduction and biodiversity conservation: rebuilding the bridges. Oryx 38:137-139. http://dx.doi.org/10.1017/S0030605304000249
Salafsky, N. 2011. Integrating development with conservation $-\mathrm{a}$ means to an end or a mean end to conservation? Biological Conservation 144:973-978. http://d x.doi.org/10.1016/j.biocon.2010.06.003

Salafsky, N., and E. Wollenberg. 2000. Linking livelihoods and conservation: a conceptual framework and scale for assessing the integration of human needs and biodiversity. World Development 28:1421-1438. http://dx.doi.org/10.1016/ $\underline{\mathrm{S} 0305-750 \mathrm{X}(00) 00031-0}$

Sanderson, S. 2005. Poverty and conservation: the new century's "peasant question"? World Development 33:323-332. http://dx.doi.org/10.1016/j.worlddev.2004.07.016

Sanderson, S. E., and K. H. Redford. 2003. Contested relationships between biodiversity conservation and poverty alleviation. Oryx 37:389-390. http://dx.doi.org/10.1017/S003 $\underline{060530300070 X}$

Sandker M., B. M. Campbell, and N. Zacharie. 2009. Exploring the effectiveness of integrated conservation and development interventions in a Central African forest landscape. Biodiversity and Conservation 18:2875-2892. htt p://dx.doi.org/10.1007/s10531-009-9613-7

Sayer, J. 2009. Reconciling conservation and development: are landscapes the answer? Biotropica 41:649-652. http://dx.d oi.org/10.1111/j.1744-7429.2009.00575.x

Sayer, J., and B. M. Campbell. 2004. The science of sustainable development: local livelihoods and the global environment. Cambridge University Press, Cambridge, UK.

Sayer, J., B. M. Campbell, L. Petheram, M. Aldrich, M. Ruiz Perez, D. Endamana, Z. Nzooh Dongmo, L. Defo, S. Mariki, N. Doggart, and N. Burgess. 2007. Assessing environment and development outcomes in conservation landscapes. Biodiversity Conservation 16:2677-2694. http://dx.doi.org/10 $.1007 / \mathrm{s} 10531-006-9079-9$

Schmidt-Soltau, K., and D. Brockington. 2007. Protected areas and resettlement: what scope for voluntary relocation? World Development 35:2182-2202.

Schmink, M., and J. Jouve-Martin. 2011. Editors' foreword: contemporary debates on ecology, society, and culture in Latin America. Latin American Research Review 46:3-10. http://dx. doi.org/10.1353/lar.2011.0036

Schwartzman, S., D. Nepstad, and A. Moreira. 2000. Arguing tropical forest conservation: people versus parks. Conservation Biology 14:1370-1374. [online] URL: http://dx. doi.org/10.1046/j.1523-1739.2000.00227.x

Scott, W. R., R. E. Levitt, and R. J. Orr, editors. 2011. Global projects: institutional and political challenges. Cambridge University Press, New York, USA. 
Shackleton, S., P. Shanley, and O. Ndoye. 2007. Invisible but viable: recognizing local markets for non-timber forest products. International Forestry Review 9:697-712. http://dx. doi.org/10.1505/ifor.9.3.697

Somanathan, E., R. Prabhakar, and M. B. Singh. 2010. Decentralization for cost-effective conservation. Proceedings of the National Academy of Sciences 106:4143-4147. [online] URL: http://dx.doi.org/10.1073/pnas.0810049106

Stiglitz, J. E. 2006. Making globalization work. W. W. Norton and Company, New York, USA.

Stringer, L. C., A. J. Dougill, E. Fraser, K. Hubacek, C. Prell, and M. S. Reed. 2006. Unpacking "participation" in the adaptive management of social-ecological systems: a critical review. Ecology and Society 11(2):39. [online] URL: http://w ww.ecologyandsociety.org/vol11/iss2/art39/

Sunderland, T. C. H, C. Ehringhaus, and B. M. Campbell. 2008. Conservation and development in tropical forest landscapes: a time to face the trade-offs? Environmental Conservation 34:276-279.

Sunderlin, W. D., and H. Thu. 2005. Poverty alleviation and forests in Vietnam. Center for International Forestry Research (CIFOR), Bogor, Indonesia.

Tallis, H., P. Kareiva, M. Marvier, and A. Chang. 2008. An ecosystem services framework to support both practical conservation and economic development. Proceedings of the National Academy of Sciences 105:9457-9464. [online] URL: http://dx.doi.org/10.1073/pnas.0705797105

United Nations Economic and Social Commission for Asia and the Pacific (UN-ESCAP). 2009. Participatory approaches to rural development and rural poverty alleviation. Working Paper. [online] URL: http://www.unescap.org/pdd/publications/ poverty and development/participatory rural.pdf [accessed on $02 / 01 / 2012$ ].

Wells, M. P., T. O. McShane, S. O'Connor, and H. Redford. 2004. The future of integrated conservation and development projects: building on what works. Pages 397-422 in T. McShane, and M. Wells, editors. Getting biodiversity projects to work: towards more effective conservation. Columbia University Press, New York, USA.

Whyte, W. F., editor. 1991. Participatory action research. Sage Focus editions, Vol. 123. Sage, Thousand Oaks, California, USA.

Wilkie, D., G. Morelli, J. Demmer, M. Starkey, P. Telfer, and M. Steil. 2006. Parks and people: assessing the human welfare effects of establishing protected areas for biodiversity conservation. Conservation Biology 20:247-249.
Wunder, S. 2001. Poverty alleviation and tropical forestswhat scope for synergies? World Development 29:1817-1833. http://dx.doi.org/10.1016/S0305-750X(01)00070-5

Wunder, S. 2005. Payments for environmental services: some nuts and bolts. CIFOR Occasional paper 42. Center for International Forestry Research, Bogor, Indonesia.

Wunder, S. 2007. The efficiency of payments for environmental services in tropical conservation. Conservation Biology 2:48-58. http://dx.doi.org/10.1111/j.1523-1739.2006 .00559.x

Wunder, S., S. Engel, and S. Pagiola. 2008. Taking stock: a comparative analysis of payments for environmental services programs in developed and developing countries. Ecological Economics 65:834-852. http://dx.doi.org/10.1016/j.ecolecon. $\underline{2008.03 .010}$

Zimmerer, K. S., and T. J. Bassett. 2003. Approaching political ecology: society, nature and scale in human-environmental studies. Pages 1-28 in K. S. Zimmerer, and T. J. Bassett, editors. Political ecology: an integrative approach to geography and environment-development studies. Guilford Press, New York, NY, USA.

Zimmermann, F., and K. Smith. 2011. More actors, more money, more ideas for international development cooperation. Journal of International Development 23:722-738. http://dx.d oi.org/10.1002/jid.1796 